\title{
The Windowless Room of the Present: Rereading David Harlan
}

\author{
Herman Paul | ORCID: 0000-0002-9365-6329 \\ Institute for History, Leiden University, Leiden, The Netherlands \\ h.j.paul@hum.leidenuniv.nl
}

\begin{abstract}
This essay unearths the guiding question of David Harlan's 1997 book, The Degradation of American History. While most commentators have focused their attention on Harlan's biting criticism of the historical profession, this essay argues that Harlan's diatribe against historical scholarship pursued "for its own sake" stems from a deep concern about the moral education of citizens in an age that François Hartog and others typify as "presentist." Although Harlan's remedies against presentism are found wanting, the essay argues that the question raised in The Degradation of American History is a relevant, timely, and still unresolved one, now even more than at the time of the book's original publication.
\end{abstract}

\section{Keywords}

David Harlan - presentism - regimes of historicity - temporality - moral education

In the past decade or two, "presentism" has proved a fertile area of study for philosophers of history. ${ }^{1}$ Referring to ways of living or modes of thinking that are focused more on the present than on the past or the future, presentism is a diagnostic concept that is used most often these days in critical reflections on what François Hartog calls "a world so enslaved to the present that no

1 As demonstrated by Rethinking Historical Time: New Approaches to Presentism, ed. Marek Tamm and Laurent Olivier (London: Bloomsbury, 2019). 
other viewpoint is considered admissible." ${ }^{2}$ Even though the empirical claim that large parts of the contemporary world suffer from presentism so defined is subject to debate, ${ }^{3}$ most authors agree on the normative claim that a shrinking temporal horizon - one that leaves little room for past experiences or anticipations of the future - is a sign of impoverishment, both intellectually and morally. This explains why studies such as Jérôme Baschet's recent book on "the tyranny of the present" discuss anti-globalist movements like the Zapatistas in Mexico in the hope of identifying resources for "micro-resistance" against the hegemony of presentist regimes of time (as enforced upon the Mexican population by a political regime that, until recently at least, pursued a broadly neoliberal agenda, especially in areas like forestry). ${ }^{4}$

As refreshing as it is to see philosophers of history writing about rainforests and timber harvesting instead of narrative sentences and intentional explanations, the question is why authors like Baschet need Mexican guerilla movements for creating a hole in "the windowless room of the present" if their own professional practice - teaching students how to engage with past realities and writing books that transmit historical knowledge to wider audiences - has the potential of creating such vistas beyond the present, too. One possible answer is that philosophers of history welcome themes like presentism, modes of temporality, and regimes of historicity as means for moving "beyond the confines of the historian's workshop." ${ }^{6}$ In addition, one might argue that the challenges posed by global capitalism and climate change are such that all academics, philosophers of history included, have a duty to engage with how societies configure their relations to present, past, and future (with special attention perhaps to the kind of futures that their narratives of temporality enable or foreclose). ${ }^{7}$ Still, this leaves us with the question to what extent the historian's own practice also has the potential for stretching our temporal horizons and confronting us with ideas, practices, or concepts that challenge the wisdom of our peers, our employers, or the media that shape our understanding of the world. Can historical writing and teaching increase the cultural repertoires

2 François Hartog, Regimes of Historicity: Presentism and Experiences of Time, trans. Saskia Brown (New York: Columbia University Press, 2015), xiii.

3 See, e.g., Zoltán Boldizsár Simon, History in Times of Unprecedented Change: A Theory for the 21st Century (London: Bloomsbury, 2019), 4-9.

4 Jérôme Baschet, Défaire la tyrannie du présent: temporalités émergentes et futurs inédits (Paris: La Découverte, 2018).

5 As far as I know, this phrase was first used by Gerald F. Else in James E. Haney, "Humanities: A Classical Dialogue," Humanities 2, no. 5 (1972), 1-8, at 2.

6 Amin Samman, History in Financial Times (Stanford, CA: Stanford University Press, 2019), 92.

7 Zoltán Boldizsár Simon and Marek Tamm, "Historical Futures," History and Theory 6o, no. 1 (2021), 3-22. 
with which we navigate our lives, thereby expanding our imagination beyond the confines of the present?

This, I would argue, is the key question posed in David Harlan's often misunderstood and already half-forgotten book The Degradation of American History (1997). ${ }^{8}$ Although Harlan was part of a broader "moral turn" in American historiography, ${ }^{9}$ he remains to date one of the very few historical theorists who have explored the question of how and to what extent historical studies can help expand the moral horizons of present-day citizens. While there is no lack of studies exploring the ethics of historical research and writing as such, ${ }^{10}$ The Degradation of American History distinguishes itself from this body of literature by raising a much broader question: To what extent can historical inquiry help people overcome the limitations of their present moral convictions? Does it have anything to offer to people who long to break out of their "temporal provincialism"?"1 Although I find myself disagreeing with Harlan on several important points, some of which I will mention below, I believe that the question guiding Harlan's book is not only an important one, but also one to which philosophers of history working on presentism and related themes might be more receptive than they or their colleagues were at the time when The Degradation of American History appeared.

\section{2 The State of the Profession}

Indeed, judging by book reviews from the late 199os - I have found twelve of them, including a lengthy review essay in History and Theory - many readers did not find it easy to identify Harlan's guiding question. ${ }^{12}$ His book was mostly

8 At the time of publication, Harlan taught in the history department at California Polytechnic State University, San Luis Obispo. From 2004 to 2008, he co-edited the journal Rethinking History.

9 George Cotkin, "History's Moral Turn," Journal of the History of Ideas 69, no. 2 (2008), 293-315.

10 See, e.g., Robert Doran, The Ethics of Theory: Philosophy, History, Literature (London: Bloomsbury, 2016); The Ethics of History, ed. David Carr, Thomas R. Flynn, and Rudolf A. Makkreel (Evanston, IL: Northwestern University Press, 2004); and the theme issue "Historians and Ethics," History and Theory 43, no. 4 (2004).

11 I borrow this term from Aviezer Tucker, "Temporal Provincialism: Anachronism, Retrospection and Evidence," Scientia Poetica 10 (2006), 299-317.

12 As Casey N. Blake's review in The Journal of American History 86, no. 1 (1999), 200-201 put it: "David Harlan is waging so many historiographical battles on so many fronts in this collection that readers may be excused if they find themselves mystified by his confusing alliances and often contradictory pronouncements" (200). 
read as a cri de coeur about the sorry state of the American historical profession near the end of the twentieth century. Reviewers identified, not incorrectly, two reasons for Harlan being frustrated about recent developments in his field. The first and most important one was a lack of moral relevance, caused by a growing gap between professional historical studies and moral deliberation in American society at large. Whereas mid-twentieth century historians like Perry Miller, the widely read scholar of New England Puritanism, had still been able to bridge the two worlds with books that were moral interventions as much as historical interpretations, later generations learned upon entering graduate school that "professionalism" was incompatible with "moralism." Socialized into an ethos of what Harlan disapprovingly calls "healthy-minded, Vaseline-impregnated, responsible-sounding professional Methodism,"13 they no longer regarded themselves as translators between past and present, but as seekers of knowledge "for its own sake." Harlan's narrative thus takes the archetypical form of what one reviewer called "a golden age" followed by "a fall from grace" that drove morally informed history writing into long-term exile. ${ }^{14}$

A second concern that reviewers detected in the pages of Harlan's book was a discontentedness with "objectivity" still serving as the profession's holy grail not in the crude, positivistic version that American historians once cherished in their search for scientific credibility, ${ }^{15}$ but in more modest, neo-pragmatic variants as developed by David A. Hollinger and Thomas L. Haskell. ${ }^{16}$ This second concern is related to the first one insofar as Harlan sees the quest for objective historical knowledge as an obstacle to moral relevance. To the surprise of several reviewers, this leads him to enlist a broad range of purportedly "postmodern" authors as allies in his effort to revitalize a morally relevant type of history writing - as if the moral muses move back into the house of history as soon as the ghost of objectivity is exorcized. In the words of Casey N. Blake: "Traditionalists who cannot abide Jacques Derrida and Michel Foucault and

13 David Harlan, The Degradation of American History (Chicago, IL: University of Chicago Press, 1997), 153. Subsequent references will appear in parentheses in the text.

14 Keith Jenkins, review in Rethinking History 2, no. 3 (1998), 409-412, at 409. Jenkins discusses Harlan's book at greater length in his Why History? Ethics and Postmodernism (London: Routledge, 2005), 184-200.

15 Peter Novick, That Noble Dream: The "Objectivity Question" and the American Historical Profession (Cambridge: Cambridge University Press, 1988), 21-108.

16 See, most notably, Thomas L. Haskell, "Objectivity is not Neutrality: Rhetoric vs. Practice in Peter Novick's That Noble Dream," History and Theory 29, no. 2 (1990), 129-157. 
poststructuralists who do not read the Puritans may well wonder how they ended up as allies in such an insurgency."17

Arguably, however, by singling out the ideal of objectivity and the moral relevance of academic historiography as key issues for debate, Harlan's reviewers offered their readers a rather narrow interpretation of The Degradation of American History. Instead of highlighting Harlan's worries about the moral imagination of American citizens in an age preoccupied with the here and now, they focused their attention on the accuracy of his assessment of the historical profession. They frowned on Harlan's tendency to equate the field of intellectual history with the profession at large, thereby ignoring all the work done by social and economic historians. ${ }^{18}$ Some criticized Harlan's idealizing portrayal of the "Western Civilization" course that freshman students once attended in great numbers. ${ }^{19}$ Others wondered why Harlan had so little patience with academics "who find it worthwhile, even fascinating, to reconstruct the past doings of human beings with all possible care and diligence." ${ }^{20}$ Also, in assessing Harlan's vision of historians shifting their attention from archival research to conversations across time, reviewers showed themselves concerned about the price that the historical profession would have to pay for it. "[W]e would greatly impoverish our profession" by attending to Harlan's advice, warned a Canadian reviewer. ${ }^{21}$ History would become, if not "a redundant form of literature," then just another form of cultural criticism. ${ }^{22}$ Indeed, both critics and admirers agreed that history as envisioned by Harlan would no longer deserve the name "history." 23

This focus on the state and prospects of the historical profession - prompted perhaps by the not entirely felicitous title of Harlan's book - was so dominant that only three reviewers touched in passing on the more important question

17 Blake, review in The Journal of American History, 200.

18 David J. Russo, review in Canadian Journal of History 33, no. 1 (1998), 133-135, at 133; Christopher Kent, "Historiography and Postmodernism," Canadian Journal of History 34, no. 3 (1999), 385-415, at 402; Richard Wightman Fox, review in The Journal of Southern History 65 , no. 3 (1999), 681-682, at 681.

19 Russo, review in Canadian Journal of History, 134. The history of this legendary freshmanlevel course, offered at many American colleges between the 1920s and the 196os, has been documented by Gilbert Allardyce, "The Rise and Fall of the Western Civilization Course," The American Historical Review 87, no. 3 (1982), 695-725.

20 Joyce Appleby, review in Pacific Historical Review 67, no. 4 (1998), 6o9-610, at 6o9.

21 Russo, review in Canadian Journal of History, 135.

22 Richard A. Buitron, review in History: Reviews of New Books 26, no. 4 (1998), 172; Blake, review in The Journal of American History, 200.

23 Ibid.; Jenkins, review in Rethinking History, 411-412. 
that Harlan wanted to put on the table: How can historical studies enrich the moral imagination of citizens in an age that does not exactly encourage people to engage with ideas, practices, or beliefs older than the day before yesterday? ${ }^{24}$

To recognize this as the key question animating Harlan's book, it helps, for a start, to look at the author's personal pronouns, "we" and "our" in particular. If Harlan speaks about "our primary form of moral reflection," the first-person plural does not refer to historians, but to "we, as a people" (xv). Likewise, if Harlan argues that "we" have lost "our" understanding of the past as a repository of ideas and practices on which we can draw in pondering "what we should value and how we should live" (xviii), the first-person plural denotes a community of readers outside the walls of academia. Indeed, throughout the book, "our" wants and desires (203), "we" inscribing ourselves in time (207), and "we" stumbling upon values that turn out to be valuable "for us" (211) are phrases that refer to ordinary citizens attempting to navigate the complexities of late-modern life. Historians, by contrast, are typically, though not consistently (see, e.g., xxxi, 52, 132), referred to in the third-person plural: "Though they write at the very end of the American century, they feel no need to say ... what is worth insisting on and saving" (xv). Even if Harlan deals with historians whom he admires, such as Perry Miller, he does not identify with the author, but with his readers: "For by showing us how to think with our predecessors' thought ... he [Miller] taught us how to place ourselves in time ..." (xviii).

A second indication of Harlan being primarily concerned about the moral imagination of American citizenry at large is his choice of interlocutors. Harlan's main conversation partners are not historians, but philosophers and literary scholars. Although he could easily have devoted a chapter to historians like Eugene Genovese, whose 1994 book, The Southern Tradition, offers almost exactly the kind of moral reflection that Harlan is looking for, ${ }^{25}$ he actually prefers to engage with public intellectuals such as the literary critic Henry Louis Gates Jr. and the philosopher Richard Rorty. By unearthing a rich tradition of African American novelist writing, says Harlan, Gates confronts

24 R. A. Burchell, review in History 84, no. 276 (1999), 669-670, at 670; Fox, review in The Journal of Southern History, 682; Raymond Martin, "History as Moral Reflection," History and Theory 39, no. 3 (200o), 405-416, at 412.

25 Eugene D. Genovese, The Southern Tradition: The Achievements and Limitations of an American Conservatism (Cambridge, MA: Harvard University Press, 1994). 
us, the American people, with "predecessors we did not even know we had" (186). Gates, in other words, opens up new futures by uncovering new pasts. Similarly, Harlan admires Rorty for reviving a liberal tradition in American political life with help of Deweyan pragmatism and Derridean postmodernism (135). For Harlan, then, Gates and Rorty are sources of inspiration to the extent that they make historical resources available to present-day citizens - not with the aim of increasing their knowledge of the past, but to give them tools for thinking about their presents and futures.

What these tools entail becomes evident, in the third place, from Harlan's argument that engaging with ideas and practices from the past amounts to a "spiritual exercise" aimed at expanding the moral imagination. ${ }^{26}$ Not unlike Wayne C. Booth and Martha C. Nussbaum in the field of literary studies, Harlan advocates a kind of "ethical criticism," focused on how cultural encounters with people committed to other values than those en vogue in the present can enlarge one's moral horizons. ${ }^{27}$ If people are fortunate enough to find "mentors and nestors" (147) among the dead, their "patterns of perception and desire" (189) will be shaped not merely by hegemonic powers in the present - think of late-capitalist consumerism - but also by models that embody alternative ways of living. Although the argument that historical figures can "teach us what to want, what to value, who to admire" (155) seems reminiscent of the old historia magistra vitae tradition, it is important to highlight that it differs from the latter in one crucial respect. Instead of assuming that past and present are sufficiently similar to allow historical exempla to be emulated long after their death, Harlan seeks models that are different from those propagated by the moral powers-that-be. For him, ideas or practices from the past serve as moral "counter resources" (44), which are valuable to the extent that they challenge current-day wisdom. ${ }^{28}$

It is only against this background that Harlan eventually raises the question: What can historians contribute to such "counter formation" of the moral self? Or more fundamentally: Do historians realize what it is that "we need" from them $(34,96)$, namely, a history that teaches us "how to think with our

26 I borrow this phrase (not used by Harlan himself) from Pierre Hadot, Philosophy as a Way of Life: Spiritual Exercises from Socrates to Foucault, ed. Arnold I. Davidson, trans. Michael Chase (Oxford: Blackwell, 1995).

27 Wayne C. Booth, The Company We Keep: An Ethics of Fiction (Berkeley, CA: University of California Press, 1988); Martha C. Nussbaum, Love's Knowledge: Essays on Philosophy and Literature (New York: Oxford University Press, 1990).

28 Despite its Foucauldian ring, "counter resources" is a term that Harlan takes from Louis Hartz, The Liberal Tradition in America: An Interpretation of American Political Thought since the Revolution (New York: Harcourt, Brace and Company, 1955), 12. 
predecessors' thought" (xxiii)? It may well be that historical research since the days of Perry Miller has become more subtle and sophisticated. But that is not the point. When Harlan speaks about the "degradation" of American historiography, this strong word expresses something else: a sense of disappointment that historians fail to help us, ordinary citizens, getting out of the windowless room of the present. Why have historians, some exceptions notwithstanding, deserted a public that hoped, and still hopes, to enrich its moral imagination with input from the past?

I believe that these questions are pertinent ones, even if the answers that Harlan subsequently develops are not always convincing. Indeed, as reviewers did not fail to point out, some of these answers leave much to be desired. Apart from that Harlan's arguments are not always very clear - his penchant for rhetorical questions sometimes obscures the details of what he wants to say ${ }^{29}$ - the eagerness with which the author sacrifices historians' professional habits ("always contextualize") for the sake of regaining moral relevance struck almost all reviewers as infelicitous. Kerwin Lee Klein, for instance, noticed that Harlan employs a Manichean logic that few would call convincing:

On the one side of the story, we find contextualism, intentionality, pragmatism, leftists, social science, and error. On the other side of the binary divide, we find textualism, Great Books, moral imagination, and a host of prophetic figures. These antitheses are not problematized, questioned, subverted, or negotiated. Harlan imagines them as a fork in the highway of life: That way lies evil. ${ }^{30}$

Related to this all-determining dichotomy is a host of unresolved difficulties. To what extent, for instance, does moral deliberation benefit from a deliberate ignoring of historical contexts? Speaking about Walt Whitman's "Song of Myself" (1855), Harlan argues like an old New Critic that he is interested in the content of this celebrated poem, not in its context. Consequently, in response to historians who point out that Whitman himself did not exactly live up to his

29 Martin, "History as Moral Reflection," 409-410, 412.

30 Kerwin Lee Klein, review in The William and Mary Quarterly 56, no. 2 (1999), 420-423, at 422. See also Kent, "Historiography and Postmodernism," 401: "Harlan has no use for the middle of the road: with him it's all or nothing." 
moral vision, ${ }^{31}$ Harlan shrugs his shoulders: "The only Whitman that matters to us is the Whitman who emerges from his poems" (211). In matters moral, however, closing one's eyes or looking away is not exactly a strategy for gaining deep insight. As Raymond Martin put it: "We might be led to more serious moral reflection by the realization, if it were true, that Whitman was a contradiction." 32

Harlan is unclear, moreover, about the degree of "otherness" that is needed for ideas, texts, or images to make a difference in the moral imagination of present-day people. On the one hand, he emphasizes that current generations should not hesitate to project their own questions, problems, and vocabularies back upon the past: "[W]e must put history to the rack, we must compel it to answer our questions. Our questions, derived from our needs, couched in our terms" (30). On the other hand, Harlan maintains that "criticizing the present" (xvi) is the goal of all attempts at dialogue across time. Reading history "against ourselves" $\left(3^{2}, 5^{2}\right)$ is unlikely to take place, however, as long as we impose our own questions, problems, and vocabularies upon the past. If Jonathan Edwards - one of Harlan's favorite examples - is to challenge twentyfirst-century readers, he can do so only if he is allowed to speak in his own, Calvinist idiom about humans being "justified by Faith and not by Works." ${ }^{33}$ But if the otherness of the past is a sine qua non for receiving moral instruction of a kind we could not have obtained from contemporaries, ${ }^{34}$ how can Harlan be so nonchalant about interpretations that strip historical texts from what modern readers perceive as "outdated foolishness"? 35

Finally, on a more practical note, is it true that American citizens are knocking on university doors, eager to get instructed about Plato, Aristotle, and Augustine? By focusing on a waning supply of morally engaged historiography, more than on society's demand for it, Harlan has little to say about the extent to which people are actually interested in buying morally edifying

31 Harlan refers specifically to David S. Reynolds, Walt Whitman's America: A Cultural Biography (New York: Alfred A. Knopf, 1995).

32 Martin, "History as Moral Reflection," 412.

33 Jonathan Edwards, A Treatise Concerning Religious Affections (Boston, MA: S. Kneeland and T. Green, 1746), 338.

34 As I argue in Herman Paul, Key Issues in Historical Theory (New York: Routledge, 2015), $123-138$.

35 Richard Rorty, "The Historiography of Philosophy: Four Genres," in Philosophy in History: Essays on the Historiography of Philosophy, ed. Richard Rorty, J. B. Schneewind, and Quentin Skinner (Cambridge: Cambridge University Press, 1984), 49-75, at 52, commenting on Peter Strawson's creative re-interpretation of Immanuel Kant in The Bounds of Reason: An Essay on Kant's “Critique of Pure Reason” (London: Methuen \& Co., 1966). 
history books. ${ }^{36}$ In addition, one might argue that insofar as people have an interest in times other than their own, their demand is well fulfilled by novelists, film makers, or game designers. Even such seemingly unfashionable figures as Harlan's New England Puritans - seventeenth-century divines whose Augustinian leanings Harlan believes to offer a much-needed corrective to the modern vice of inflated self-confidence (xxiv, xxvi) - are nowadays the subject of exhibitions, public talks, and books of fiction. If the Pulitzer Prize-winning novelist Marilynne Robinson travels across the United States to lecture on the continuing relevance of Puritan sensibilities and finds herself being interviewed by no less than Barack Obama about the doctrine that humans are created in the image of God, one may even wonder what a Miller redivivus would have to add to this. ${ }^{37}$ Isn't Harlan's conversation with the dead already taking place in churches, book clubs, and public libraries? ${ }^{38}$

Although I think these are important points of criticism, I notice that they are focused almost entirely on Harlan's "position" - that is, on how the author answers his question about the role that historians can play in expanding people's moral horizons. There is reason to wonder, however, whether that is the best way of doing justice to a book. Following Nicholas Jardine, who in his turn draws on R. G. Collingwood, one might argue that the question a book seeks to raise is at least as important as the answer it proposes. ${ }^{39}$ This is not merely because "positions" can be understood only if the questions to which they respond are adequately grasped, ${ }^{40}$ but also because the questions that authors try to put on the agenda are sometimes more interesting than the answers they develop. This, I would argue, is the case with The Degradation of American History. Even though I find myself agreeing with most of the reviewers' critical remarks, I think these criticisms are no reason for dismissing the book. What makes The Degradation of American History worth reading, now even more than at the time of publication, is the question it raises - a question that I would call relevant, timely, and still unresolved.

36 As Wayne Booth already knew, one can never assume a priori that one's intended audience has a "desire to be taught" (Company We Keep, 210).

37 Marilynne Robinson, What Are We Doing Here? Essays (New York: Farrar, Straus, and Giroux, 2018); "President Obama and Marilynne Robinson: A Conversation in Iowa," The New York Review of Books 62, no. 17 (2015), 4-8 and 62, no. 18 (2015), 6-8.

38 Harlan admits as much in his more recent essay, "Historical Fiction and the Future of Academic History," in Manifestos for History, ed. Keith Jenkins, Sue Morgan, and Alun Munslow (London: Routledge, 2007), 108-130.

39 Nicholas Jardine, The Scenes of Inquiry: On the Reality of Questions in the Sciences (Oxford: Clarendon Press, 1991).

$40 \quad$ R. G. Collingwood, An Autobiography (Oxford: Clarendon Press, 1939), 31. 
Examining how historians can help us expand our temporal horizons is a relevant issue, first of all, because of the challenges that our societies are facing. While wicked problems such as climate change and coviD-19 obviously require technical and medical responses, they also make demands on the human imagination. In particular, they raise a question about the appropriateness of terms like "crisis" - a currently all-pervasive word that may aptly express the experience of witnessing unprecedented events, but also, at the same time, discourages people to develop alternatives to dichotomies of the kind that either we are going to fix these problems technologically, with vaccines and carbon capture and storage, or there is nothing we can do to avoid an apocalypse. Arguably, though, there is a need for such alternatives, if only because they can help us recognize to what extent the language of crisis has a tendency to narrow our attention to technological "problems" and "solutions." As climate scientist Mike Hulme argues with regard to climate change, such technological perspectives are fruitful only if they are embedded in larger visions of the future. We need stories of impending disaster ("apocalypse," "point of no return") to urge us to rethink our habits of consumption, but also, no less importantly, stories of meaning and purpose ("human rights," "environmental justice") to make us think what kind of world we want to preserve. ${ }^{41}$ From this perspective, engaging with "our predecessors' thought" may be a way of stretching our imagination beyond the either-or scenarios dominant in our present age.

Arguably, historical study is not unique in being capable of challenging the stories we live by. Apart from Baschet's Zapatistas, literary fiction may also be able to confront us with new interpretative habits, heighten our sense of narrative possibility - climate change as tragedy, as romance, or as satire? - and sharpen our sensitivity to what hegemonic discourses reveal and obscure. ${ }^{42}$ Nonetheless, even if historical study is not unique or privileged in this regard, engaging with the stories, hopes, and fears of people in times past remains a particularly powerful way of broadening the range of cultural repertoires available to us. If the challenge of our time is to face an uncertain future with courage, responsibility, and wisdom, Harlan's question about what role historians

41 Mike Hulme, Why We Disagree about Climate Change: Understanding Controversy, Inaction and Opportunity (Cambridge: Cambridge University Press, 2009), 322-365.

42 Amitav Ghosh, The Great Derangement: Climate Change and the Unthinkable (Chicago, IL: University of Chicago Press, 2016). 
can play in expanding our moral imagination is therefore a question of undisputed relevance.

From a humanities point of view, Harlan's question is also a timely one. I say so not only because presentism has entered the scholarly conversation or because "environmental humanities" has become a thriving field. ${ }^{43}$ More fundamentally, historians and other humanities scholars increasingly find themselves working in academic settings that no longer allow them to engage in research "for its own sake." A combination of forces that includes a growing societal demand for "valorization" or "knowledge transfer" compels them to explain much more explicitly than before what they are able to contribute to societies wrestling with more urgent problems than, say, the causes of the War of the Spanish Succession. ${ }^{44}$ This helps explain why the persona of the historian is receiving so much attention these days: the inherited model of a scholar who immerses him- or herself in archival research with the aim of writing a specialized monograph no longer meets societal expectations. ${ }^{45}$ Accordingly, the existence of a profession devoted to the study of the human past has become less self-evident than it still was in the 199os, when Harlan's book was met with skeptical or even ironic responses from professional historians ("Forget being an archival sleuth; hone your skills at transgenerational conversations instead"). ${ }^{46}$ What back then might have seemed a rhetorical ploy has now, less than thirty years later, become a real question: "Can the humanities survive if they abandon their traditional responsibility of helping us think about what we should value and how we should live?" (xxiii).

Finally, Harlan's question is an unresolved one, at least insofar as his own answers have remained underdeveloped and are not always pointing in promising directions. As I explained above, there is something deeply unconvincing about the author's deliberate indifference to historical contexts. Also, if Harlan wants past voices to challenge present-day orthodoxies, attentiveness to the distinctive "otherness" of these voices would seem more productive than a celebration of creative, anachronistic reinterpretations. Moreover, even readers who are broadly sympathetic to Harlan's claim that historical study reaches its

\footnotetext{
43 Robert S. Emmett and David E. Nye, The Environmental Humanities: A Critical Introduction (Cambridge, MA: мIт Press, 2017).

44 Daniel Wutti and Markus Hayden, "Knowledge Transfer in the Social Sciences and Humanities (sSH): Definition, Motivators, Obstacles, and Visions," Colloquium 2, no. 1 (2017), 87-101.

45 As I argue at greater length in Herman Paul, "Sources of the Self: Scholarly Personae as Repertoires of Scholarly Selfhood," Low Countries Historical Review 131, no. 4 (2016), 135154, at $147^{-15}$.

46 Appleby, review in Pacific Historical Review, 6og.
} 
highest goal in contributing to the moral formation of human individuals are left wondering: How exactly does that look in practice? Why does Harlan consistently focus on what historians write, whereas conversing with voices from the past is an activity that seems more at home in the classroom (or, indeed, in book shops and reading groups outside of university campuses)? I would be prepared to argue indeed that historians primarily engage in moral education by teaching their students. Insofar as they open up new horizons, they do so, first and foremost, by introducing students to cultures with different moral codes and ways of life. Insofar as historians create holes in the windowless room of the present, they do so primarily by exposing students to cultural repertoires that they would not normally encounter on Instagram or Facebook.

So where does this leave us? As Arthur O. Lovejoy once declared, "To study history is always to seek in some degree to get beyond the limitations and preoccupations of the present." ${ }^{27}$ I read The Degradation of American History as a passionate plea to place this struggle against temporal provincialism right in the heart of historical studies. I interpret Harlan as arguing that historians should help citizens see beyond the preoccupations of the present and provide them with resources for thinking about "what to want, what to value, [and] who to admire." Although I am not persuaded by Harlan's argument that such a project would require historians to abandon their traditional care for contextual meaning, I have emphasized that the question animating Harlan's book is a relevant, timely, and still unresolved one, worthy of being addressed anew, not only by philosophers of history, but by a broad range of historians and other humanities scholars. In a context of climate change and zoonotic diseases, Harlan's question about what historians can add to the moral wisdom of the present has become more urgent than ever.

If I recommend The Degradation of American History specifically to philosophers of history, I do so, on the one hand, with an eye to their burgeoning scholarship on presentism, but also, on the other, because of their not yet fully developed interest in how historical studies might contribute to overcoming temporal provincialism. By attending to that question, philosophers of history might give a new twist to the study of hegemonic regimes of historicity. Instead of locating potential sources of resistance in quasi-utopian projects like the

47 Arthur O. Lovejoy, "Present Standpoints and Past History," The Journal of Philosophy 36, no. 18 (1939), 477-489, at 482. 
Zapatista insurgence - fascinating in its own right, but out of reach for most citizens across the globe - they might explore how the writing and, especially perhaps, the teaching of history may help create holes in "the windowless room of the present." If they would do so, philosophers of history would not only address one of the most urgent questions of our time, but also help historians serve public needs without relinquishing their scholarly ethos.

\section{Acknowledgement}

I would like to thank the two anonymous reviewers for helpful feedback and Teemu Kontro and Hanna Ventomäki for copy-editing the text. Funding was generously provided by the Dutch Research Council (NwO). 